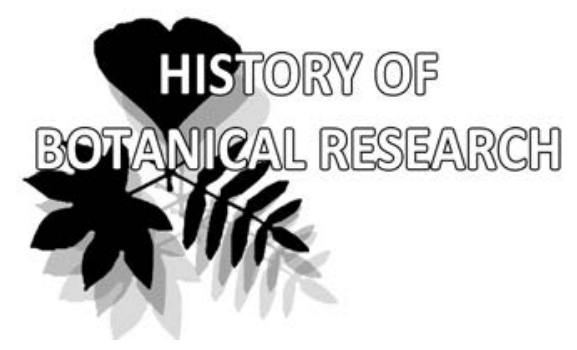

\title{
History and peculiarities of study of the Far Eastern species of Euonymus in Russia and neighboring countries
}

Ivan A. Savinov*

e-mail: savinovia@mail.ru

Russian State Agrarian University Moscow Timiryazev Agricultural Academy, Moscow, Russia

* corresponding author

Manuscript received: 06.07.2021

Review completed: 28.12.2021

Accepted for publication: 03.02.2022

Published online: 23.02.2022

\author{
Ivan A. Savinov
}

\begin{abstract}
A B S T R A C T
The Russian Far East is of particular interest to monographers of the genus Enonymus, because this is where the northern distribution limits of many East Asian species are. At the same time, the main problem is different understanding of the scope and status of a number of taxa by Russian and foreign botanists. The article presents the chronology of the most prominent results of various authors, Russian and foreign (primarily Chinese, Korean and Japanese), who contributed to taxonomic, environmental and chorological studies of the genus Euonymus. The contributions of N.S. Turczaninow, K.T. Maksimovich, F.B. Schmidt, V.L. Komarov, T. Nakai, Ya.I. Prokhanov, A.I. Tolmachev, B.A. Shukhobodsky, T.G. Leonova, N.N. Tzvelev, S.K. Cherepanov, K.V. Kiseleva, V.A. Nedoluzhko to the formation of the modern taxonomic concept of the genus Euonymus are analyzed. Unresolved issues of biology of the Far Eastern species are emphasized, the ways of to solve them are outlined.
\end{abstract}

Keywords: history of botanical research, Russian Far East, China, Korea, Japan, Euonymus

\section{P E 3 Ю M E}

Савинов И.А. История и особенности изучения Аальневосточных виАов Euonymus в России и сосеАних странах. Аальний Восток России преАстав яет особый интерес Аля монографов рода Еиопутия, поскольку здесь находятся северные границы распространения многих восточноазиатских виАов. В то же время основной проблемой явАяется разное понимание объема и статуса ряда виАов российскими и зарубежными ботаниками. В статье преАставлена хронология наиболее выАающихся результатов исследований различных авторов, российских и зарубежных (в первую очередь китайских, корейских и японских), которые внесли свой вклаА в систематику, экологию и распространение Аальневосточных видов рода Euonymus. Приведен анализ вклада Н.С. Турчанинова, К.И. Максимовича, Ф.Б. Шмилта, В.А. Комарова, Т. Накаи, Я.И. Проханова, А.И. Толмачева, Б.А. Шухободского, Т.Г. Аеоновой, Н.Н. Цвелева, С.К. Черепанова, К.В. Киселевой, В.А. НеАолужко в формирование современной таксономической концепции рода Eиопутиs. Освешены нерешенные вопросы биологии Аальневосточных видов, намечены пути их решения.

КАючевые слова: история ботанических исследований, российский Аальний Восток, Китай, Корея, Япония, Eиопутиs.
Eleven species of the genus Euonymus (Celastraceae) are found in the Russian Far East:

Euonymus alatus (Thunb.) Siebold 1827, Syn. Fl. Oecon. Jap.: 49 (Type: Japan, UPS)

Euonymus sieboldianus Blume 1827, Bijdr. Fl. Nederl. Ind.: 1147 (Type: Japan, L)

Euonymus maackii Rupr. 1857, Bull. Phys.-Math. Acad. Sci. Petersb. 15: 358 (Type: Russia, LE)

Euonymus macropterus Rupr. 1857, Bull. Phys.-Math. Acad. Sci. Petersb. 15: 358 (Type: Russia, LE)

Euonymus pauciflorus Maxim. 1859, Mém. Prés. Acad. Sci. Pétersb. Div. Sav. 9: 74 (Prim. Fl. Amur.) (Type: Russia, LE)

Euonymus oxyphyllus Miq. 1865, Ann. Mus. Bot. LugdunoBatavi 2: 86 (Type: Japan, L)

Euonymus sachalinensis (F. Schmidt) Maxim. 1882, Bull. Acad. Sci. Petersb. 27: 446 (Type: Russia, LE)

Euonymus planipes (Koehne) Koehne 1906, Mitt. Deutsch. Dendr. Ges. 15: 62 (Type: cult.*)

Euonymus sacrosanctus Koidz. 1925, Bot. Mag. Tokyo 39: 12 (Type: Japan, KYO)

Euonymus maximowiczianus Prokh. 1949, Fl. URSS, 14: 744, nom. altern. (Type: Russia, LE)

Euonymus $\times$ miniatus Tolm. 1957, Bot. Mater. Gerb. Bot. Inst. Komarova Akad. Nauk S.S.S.R., 18: 159. (Type: Russia, VLA)

Behind each species is the history of its discovery, including its collection in the nature and valid description, scientific interests and lives of botanists. 6 Euonymus species were described from the territory of the Russian Far East. This all sheds light on the understanding of plant diversity and contributes to better understanding the contemporary distribution pattern of certain species.

This article is based on the study of historical information and on the critical analysis of literary and herbarium specimens (mainly Russian herbaria, over 4000 specimens in total), acquaintance with archived materials of natural science and local history museums.

The history of study of Euonymus in the Russian Far East shows several significant stages and is summarized in Table 1. 
Table 1. The main stages in studying Euonymus of the Russian Far East and neighboring countries. For herbaria acronyms author follows Thiers (continuously updated).

\begin{tabular}{|c|c|c|c|c|c|}
\hline $\begin{array}{l}\text { Stages of } \\
\text { research }\end{array}$ & $\begin{array}{l}\text { Main researchers } \\
(*-\text { main collectors }), \\
\text { their life dates, places } \\
\text { of birth }\end{array}$ & $\begin{array}{l}\text { Collection years } \\
\text { and regions, } \\
\text { herbaria acronyms }\end{array}$ & $\begin{array}{l}\text { Described species } \\
\text { and other taxa }\end{array}$ & $\begin{array}{l}\text { Total } \\
\text { number } \\
\text { of Euony- } \\
\text { mus spp. } \\
\text { decribed/ } \\
\text { Russian } \\
\text { Far East } \\
\text { species/ } \\
\text { new spp. }\end{array}$ & Publications and notes \\
\hline \multirow{7}{*}{ Beginning } & $\begin{array}{l}\text { C.P. Thunberg (1743- } \\
\text { 1828), Jönköping, } \\
\text { Sweden }\end{array}$ & $\begin{array}{l}\text { 1775-1776, Japan, } \\
\text { UPS }\end{array}$ & $\begin{array}{l}\text { Euonymus japonicus } \\
\text { Thunb., E. tobira } \\
\text { Thunb., Celastrus alatus } \\
\text { (=Euonymus alatus } \\
\text { (Thunb.) Siebold) }\end{array}$ & $3 / 1 / 1$ & "Flora of Japan" (Thunberg 1780, 1784) \\
\hline & $\begin{array}{l}\text { P.F. von Siebold (1796- } \\
\text { 1866), Würzburg, } \\
\text { Germany }\end{array}$ & $\begin{array}{l}\text { 1823-1829, Japan, } \\
\text { L, LE }\end{array}$ & & & "Flora Japonica" (Siebold 1835) \\
\hline & $\begin{array}{l}\text { R.K. Maack* }(1825- \\
1886), \text { A(h)rensburg } \\
\text { (Kuressaare), Russia }\end{array}$ & $\begin{array}{l}\text { 1855, Amur, LE } \\
\text { 1859, Ussuri, LE }\end{array}$ & & & $\begin{array}{l}\text { Maack 1859, Regel 1862, in Russian. } \\
\text { Collections were prepared by Ruprecht } \\
\text { (1857), Regel (1861) and Maximowicz }\end{array}$ \\
\hline & $\begin{array}{l}\text { C.L. Blume (1796- } \\
\text { 1862), Braunschweig, } \\
\text { Germany }\end{array}$ & $1822-1826, \mathrm{~L}$ & $\begin{array}{l}\text { E. sieboldianus } \\
\text { Blume, E. subtriflorus } \\
\text { Blume (=E. alatus } \\
\text { (Thunb.) Siebold), } \\
\text { E. thunbergianus Blume } \\
\text { (=E. alatus (Thunb.) } \\
\text { Siebold) }\end{array}$ & $5 / 3 / 3$ & 1827 \\
\hline & $\begin{array}{l}\text { C. Ledebour } \\
\text { (1785-1851), Stralsund, } \\
\text { Germany }\end{array}$ & 1826, 1829-1831, LE & & $6 / 0 / 0$ & $\begin{array}{l}\text { "Flora Rossica" (Ledebour 1841-1842); } \\
\text { only European and Crimean-Caucasian } \\
\text { species (with a note about the collection } \\
\text { of E. verrucosus - also from "Sibiria } \\
\text { Uralensi", coll. Lessing) }\end{array}$ \\
\hline & $\begin{array}{l}\text { N.S. Turczaninow } \\
(1796-1863), \text { Nikitovka, } \\
\text { Russia }\end{array}$ & $\mathrm{KW}, \mathrm{LE}$ & $\begin{array}{l}\text { Genus Melanocarya } \\
\text { Turcz., (now as the } \\
\text { section Melanocarya } \\
\text { (Turcz.) Nakai in } \\
\text { Euonymus) }\end{array}$ & & 1858 \\
\hline & $\begin{array}{l}\text { F.J. Ruprecht }(1814 \\
\text { 1870), Freiburg im } \\
\text { Breisgau, Germany }\end{array}$ & LE & $\begin{array}{l}\text { E. maackii Rupr., } \\
\text { E. macropterus Rupr. }\end{array}$ & $2 / 2 / 2$ & $\begin{array}{l}\text { "Die ersten botanischen Nachrichten } \\
\text { über das Amurland", } 1857\end{array}$ \\
\hline \multirow{4}{*}{$\begin{array}{l}\text { Pioneer } \\
\text { studies }\end{array}$} & \multirow{2}{*}{$\begin{array}{l}\text { F.B. Schmidt*, (1832- } \\
\text { 1908), Kaisma, Russia }\end{array}$} & \multirow{2}{*}{$\begin{array}{l}\text { 1859-1862, Amur, } \\
\text { Sakhalin, LE }\end{array}$} & & $2 / 2 / 0$ & $\begin{array}{l}\text { "Amguno-Bureinskaya flora" (Schmidt, } \\
\text { 1874a; Dutch ed. - 1868) }\end{array}$ \\
\hline & & & $\begin{array}{l}\text { E. Latifolius var. } \\
\text { sachalinensis F. Schmidt }\end{array}$ & $4 / 4 / 1$ & $\begin{array}{l}\text { "Sakhalinskaya flora" (Schmidt, 1874b, in } \\
\text { Russian; Dutch ed. - 1868) }\end{array}$ \\
\hline & \multirow[t]{2}{*}{$\begin{array}{l}\text { C.J. Maximowicz* } \\
(1827-1891), \text { Tula, } \\
\text { Russia }\end{array}$} & $\begin{array}{l}\text { 1854-1857, Amur, } \\
\text { Ussuri, LE; 1860- } \\
\text { 1864, Japan, LE }\end{array}$ & $\begin{array}{l}\text { E. pauciflorus Maxim., } \\
\text { E. sachalinensis } \\
\text { (F. Schmidt) Maxim.; } \\
\text { E. ussuriensis Maxim. }\end{array}$ & $17 / 6 / 3$ & $\begin{array}{l}\text { "Primitiae florae amurensis" (Maximo- } \\
\text { wicz 1859, in Latin); "Diagnoses } \\
\text { plantarum novarum asiaticarum" } \\
\text { (Maximowicz 1881, 1882, in Latin); } \\
\text { from territories, adjacent to Russia, } \\
\text { such species as E. bungeanus Maxim., } \\
\text { E. nipponicus Maxim., E. praewalskii } \\
\text { Maxim., E. schensianus Maxim. }\end{array}$ \\
\hline & & $\begin{array}{l}\text { Central Asia, coll. } \\
\text { N.M. Przewalskii } \\
\text { (1839-1888), } \\
\text { prepared by } \\
\text { Maximowicz, LE }\end{array}$ & & & $\begin{array}{l}\text { "Flora Tangutica" (Maximowicz 1889, } \\
\text { in Latin). Based on materials provided } \\
\text { by C.J. Maximowicz, other authors have } \\
\text { described a few more species }\end{array}$ \\
\hline \multirow[t]{2}{*}{$\begin{array}{l}\text { "Flora of } \\
\text { Manchuria" } \\
\text { and others } \\
\text { floristic } \\
\text { works }\end{array}$} & $\begin{array}{l}\text { V.L. Komarov* (1869- } \\
\text { 1945), St. Petersburg, } \\
\text { Russia } \\
\end{array}$ & $\begin{array}{l}\text { 1895-1897, Amur, } \\
\text { South-Ussuri } \\
\text { Territory, Manchuria, } \\
\text { North Korea, LE, } \\
\text { LECB }\end{array}$ & $\begin{array}{l}\text { E. hamiltonianus } \\
\text { Wall. in Roxb. var. } \\
\text { maackii (Rupr.) Kom., } \\
\text { E. hamiltonianus Wall. in } \\
\text { Roxb. var. sieboldianus } \\
\text { (Blume) Kom. }\end{array}$ & $6 / 5 / 0$ & $\begin{array}{l}\text { "Flora of Manchuria" (Komarov 1904, } \\
\text { in Russian); "Introduction to the floras } \\
\text { of Mongolia and China" (Komarov } \\
1908 \text {, in Russian): } 50000 \text { specimens and } \\
\text { about } 6000 \text { species from China, Korea, } \\
\text { Japan, Mongolia and Tibet (the family } \\
\text { Celastraceae ranks 25th with its } 9 \text { genera } \\
\text { and } 84 \text { species) }\end{array}$ \\
\hline & $\begin{array}{l}\text { A.N. Krishtofovich } \\
(1885-1953), \\
\text { Krishtopovka, Russia }\end{array}$ & $\begin{array}{l}\text { 1914, 1917, Amur, } \\
\text { Sakhalin, LE }\end{array}$ & & $7 / 5 / 0$ & Krishtofovich 1914, in Russian \\
\hline $\begin{array}{l}\text { "Die } \\
\text { Naturlishen } \\
\text { Pflanzen- } \\
\text { familien" }\end{array}$ & $\begin{array}{l}\text { Ludwig Eduard } \\
\text { Theodor Loesener } \\
\text { (1865-1941), Germany }\end{array}$ & B & & & $\begin{array}{l}\text { 1st ed. }-1896,2 \text { nd ed. }-1942 ; 36 \text { species } \\
\text { out of } 60 \text { known at that time; in the } \\
\text { second edition }-96 \text { species out of } 170 \text {; } \\
\text { original system of the genus, with } 11 \\
\text { sections, which was criticized by many } \\
\text { subsequent authors (for a review see: } \\
\text { Blakelock 1951) }\end{array}$ \\
\hline
\end{tabular}


Table 1. Continued.

\begin{tabular}{|c|c|c|c|c|c|}
\hline $\begin{array}{l}\text { Stages of } \\
\text { research }\end{array}$ & $\begin{array}{l}\text { Main researchers } \\
(*-\text { main collectors }), \\
\text { their life dates, places } \\
\text { of birth }\end{array}$ & $\begin{array}{l}\text { Collection years } \\
\text { and regions, } \\
\text { herbaria acronyms }\end{array}$ & $\begin{array}{l}\text { Described species } \\
\text { and other taxa }\end{array}$ & $\begin{array}{l}\text { Total } \\
\text { number } \\
\text { of Euony- } \\
\text { mus spp. } \\
\text { decribed/ } \\
\text { Russian } \\
\text { Far East } \\
\text { species/ } \\
\text { new spp. } \\
\end{array}$ & Publications and notes \\
\hline \multirow{4}{*}{$\begin{array}{l}\text { "Flora of } \\
\text { the USSR", } \\
\text { ed. by V.L. } \\
\text { Komarov } \\
\text { and other } \\
\text { publications } \\
\text { 1940-1960s }\end{array}$} & $\begin{array}{l}\text { Ya.I. Prokhanov (1902- } \\
\text { 1965), Zheleznovodsk, } \\
\text { Russia }\end{array}$ & LE & $\begin{array}{l}\text { Genus Kalonymus } \\
\text { (Beck) Prokh.; Ser. } \\
\text { Semenowianae Prokh.; Ser. } \\
\text { Oxyphyllae Prokh.; Ser. } \\
\text { Latifoliae Prokh.; Ser. } \\
\text { Sachalinensis Prokh.; Ser. } \\
\text { Macrogemmae (Nakai) } \\
\text { Prokh.; Sect. Uniloculares } \\
\text { (Rouy et Fouc.) Prokh.; } \\
\text { E. (=Kalonymus) } \\
\text { maximowiczianus Prokh. }\end{array}$ & $16 / 8 / 1$ & $\begin{array}{l}\text { Prokhanov 1949, in Russian, English } \\
\text { edition - 1974), additions - Prokhanov } \\
1960\end{array}$ \\
\hline & $\begin{array}{l}\text { B.A. Shukhobodsky } \\
\text { (1920-?), USSR }\end{array}$ & LE, VLA & & $29 / 10 / 0$ & $\begin{array}{l}\text { "Trees and Shrubs of the USSR" } \\
\text { (Shukhobodsky 1958) }\end{array}$ \\
\hline & $\begin{array}{l}\text { A.I. Tolmachev* (1903- } \\
\text { 1979), St. Petersburg, } \\
\text { Russia }\end{array}$ & $\begin{array}{l}\text { 1947-1955, Sakhalin, } \\
\text { LE, VLA }\end{array}$ & E. $\times$ miniatus Tolm. & $6 / 6 / 1$ & $\begin{array}{l}\text { Tolmachev 1957, 1959; Tolmachev \& } \\
\text { Shukhobodsky } 1963\end{array}$ \\
\hline & S.N. Moiseenko, USSR & & & & $\begin{array}{l}\text { Moiseenko 1954, in Russian; brief review } \\
\text { of the Far Eastern species }\end{array}$ \\
\hline \multirow{2}{*}{$\begin{array}{l}\text { Monograph } \\
\text { "The genus } \\
\text { Euonymus L. } \\
\text { of the USSR } \\
\text { and neigh- } \\
\text { boring. } \\
\text { countries" }\end{array}$} & $\begin{array}{l}\text { T.G. Leonova (born } \\
\text { 1930), Leningrad, USSR }\end{array}$ & LE & & $54 / 10 / 0$ & Leonova 1974, in Russian \\
\hline & \begin{tabular}{|l|} 
E.I. Shimanovich, \\
USSR
\end{tabular} & & & $31 / 11 / 0$ & $\begin{array}{l}\text { Shimanovich 1987, in Russian; the } \\
\text { author follows the taxonomic structure } \\
\text { of the genus Euonymus proposed by } \\
\text { T.G. Leonova (1974) }\end{array}$ \\
\hline \multirow{6}{*}{$\begin{array}{l}\text { "Vascular } \\
\text { plants of } \\
\text { the Soviet } \\
\text { Far East", } \\
\text { ed. by S.S. } \\
\text { Kharkevich }\end{array}$} & $\begin{array}{l}\text { V.N. Woroshilov (1908- } \\
\text { 1999), Khomaykovo } \\
\text { (Moscow Reg.), Russia }\end{array}$ & MHA, MW, VLA & $\begin{array}{l}\text { E. alatus subsp. alatus; } \\
\text { E. alatus subsp. sacro- } \\
\text { sanctus (Koidsz.) Wo- } \\
\text { rosch.; E. macropterus } \\
\text { var. miniatus (Tolm.) } \\
\text { Worosch. }\end{array}$ & $\begin{array}{l}11 / 11 / 0 \\
8 / 8 / 0\end{array}$ & $\begin{array}{l}\text { Woroshilov 1966, 1982, in Russian; the } \\
\text { identification key for Euonymus species } \\
\text { in paper (Woroshilov 1982) should be } \\
\text { considered inappropriate }\end{array}$ \\
\hline & $\begin{array}{l}\text { K.V. Kiseleva (born } \\
\text { 1929), USSR }\end{array}$ & MW & & $10 / 10 / 0$ & $\begin{array}{l}\text { Kiseleva 1988, in Russian; excluding } \\
\text { E. oxyphyllus Miq. }\end{array}$ \\
\hline & $\begin{array}{l}\text { V.A. Nedoluzhko } \\
\text { (1953-2001), Ussuriysk, } \\
\text { USSR }\end{array}$ & VLA & \begin{tabular}{|l|} 
E. planipes subsp. \\
planipes; E. planipes \\
subsp. maximowiczianus \\
(Prokh.) Nedoluzhko
\end{tabular} & $11 / 11 / 0$ & Nedoluzhko 1995, in Russian \\
\hline & $\begin{array}{l}\text { S.K. Cherepanov } \\
\text { (1921-1995), Vyatka, } \\
\text { USSR }\end{array}$ & LE & & $19 / 10 / 0$ & Cherepanov 1994 \\
\hline & V.I. Baranov, USSR & VLA & & $6 / 6 / 0$ & $\begin{array}{l}\text { Baranov 1998, 1999, in Russian; data on } \\
\text { distribution of individual species and } \\
\text { rhythms of their seasonal development in } \\
\text { the Russian Far East are presented }\end{array}$ \\
\hline & $\begin{array}{l}\text { N.N. Tzvelev (1925- } \\
\text { 2015), Tambov, USSR }\end{array}$ & LE & & $18 / 8 / 0$ & $\begin{array}{l}\text { "Flora of Eastern Europe", ed. by } \\
\text { N.N. Tzvelev: 2004, in Russian }\end{array}$ \\
\hline \multirow[t]{2}{*}{$\begin{array}{l}\text { Current } \\
\text { studies }\end{array}$} & V.Yu. Barkalov, USSR & VLA & & $\begin{array}{l}6(7) / 6(7) / \\
0\end{array}$ & $\begin{array}{l}\text { "Flora of the Kuril Islands" (Barkalov } \\
\text { 2009); E. oxyphyllus Miq. in the Russian } \\
\text { flora (Kunashir island), the second record } \\
\text { (the first record - Tatewaki 1957: was } \\
\text { collected on Kunashir Island in 1929, and } \\
\text { kept in SAPS) }\end{array}$ \\
\hline & $\begin{array}{l}\text { I.A. Savinov (born } \\
\text { 1977), Moscow, USSR }\end{array}$ & $\begin{array}{l}\text { 2007, 2017, 2019, } \\
\text { Sakhalin, Primorye } \\
\text { Territory, MHA }\end{array}$ & & 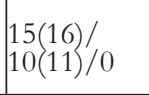 & $\begin{array}{l}\text { Savinov 2009, 2011, Savinov \& Trusov } \\
2018\end{array}$ \\
\hline
\end{tabular}

As the new data on the polymorphism and species diversity within Euonymus have been accumulated, from time to time there came a temptation to split some species into several independent ones, rejecting the broad Linnean interpretation. However, the entire history of taxonomic studies of the genus clearly demonstrates the importance of its broad treatment (Savinov \& Baikov 2007).

\section{Far Eastern species of Euonymus as treated by} Chinese taxonomic school

Out of the earlier works, the paper by Wang Chen-Hwa (1936) must be mentioned. It is of a huge interest because China is one of the main centers of species diversity for Euonymus. Wang cited diagnoses and keys for identification of 35 Euonymus species. The author also provided the 
data on distribution, herbarium specimens examined and possible relationships between certain species.

For the current "Flora of China", the authors (Ma 2001, Ma \& Funston 2008) accepted 5 sections of the genus Euonymus (Uniloculares Rouy et Foucaud, Echinococcus Nakai, Melanocarya (Turcz.) Nakai, Ilicifolia Nakai, Euonymus) and 90 species (50 of which are endemic). Unfortunately, many species from the Russian Far East territory are reduced to synonyms of closely related Chinese species there (among them there are E. planipes, E. maximowiczianus, E. $\times$ miniatus, E. sacrosanctus, E. sieboldianus, E. pauciflorus). This by no means can be considered a good solution, because, apart from clearly separated ranges, these species have solid morphological distinctions.

\section{Far Eastern species of Euonymus as treated by Korean taxonomic school}

In a series of works by Kim \& Kim (1994a-c), Kim et al. (1997) a complex approach to investigating the species diversity of Euonymus from the Korean Peninsula was introduces. It involves the analysis of morphological and anatomical features of vegetative and reproductive organs (the shape of stem and buds, leaf morphology: the shape of leaf blade, edge and top, petiole and leaf blade anatomy, structure of flowers, inflorescences and capsules), numerical analysis of 60 characters, for 16 taxa $(9$ species, 4 varieties and 3 forms). Our knowledge on Euonymus for Korean Peninsula was enriched with the new treatment by Ka (2006) for the "New flora of Korea" that includes 19 (!) species, subspecies, varieties and forms of Euonymus found on the peninsula, some of them being the same as in Russia.

Far Eastern species of Euonymus as treated by Japanese taxonomic school

Takenoshin Nakai (1882-1952) is one of the most prominent Japanese botanists, who studied not only floras of Korea and Japan, but also authored some critical monographic treatments of the genus Euonymus (Nakai 1934, 1943), In his first paper, 36 Euonymus species from Eastern Asia are investigated and subdivided into a number of sections; in the other work (Nakai 1943) he subdivided the genus Euonymus into 6 subgenera, also describing 3 new genera - Genitia Nakai, Masakia (Nakai) Nakai and Turibana (Nakai) Nakai, however, later they were included into Euonymus L. s.l. T. Nakai greatly improved the Japanese taxonomic system of Euonymus, and some sections proposed by him were accepted by other researchers. In particular, Prokhanov (1949) in the "Flora of the USSR" in general follows Nakai (1943) in delimiting the volume of sections. Some new species were also described by Nakai.

Japanese botanists (Sugawara 1940, Tatewaki 1957) contributed to the study of Euonymus diversity in Sakhalin and the southern Kuril islands.

In "Flora of Japan", Ohwi (1984, English edition, Japanese - 1965) listed 15 species of Euonymus (some of them including varieties and forms), 6 of the presented species were common in Japan and Russia, - E. alatus, E. sieboldianus, E. macropterus, E. oxyphyllus, E. planipes, E. tricarpus = E. sachalinensis.

Recent taxonomical treatments suggest that E. maximowiczianus Prokh. occurs not only in south of Primorye Territory
(Russian Far East), but also in the neighboring parts of northeast China and North Korea (in the latter case it mistakenly considered as E. sachalinensis (F. Schmidt) Maxim., incl. E. planipes (Koehne) Koenhe). E. sachalinensis (F. Schmidt) Maxim. and E. $\times$ miniatus Tolm. occurs in northern Japan (both species are considered to be E. tricarpus by Japanese authors).

The following issues of biology of the Far Eastern Euonymus species of the can be considered unresolved or underinvestigated: 1) phenology and rhythms of seasonal development in all species; 2) details of ecology and distribution of separate species, in particular, vicarious (e.g., Euonymus alatus and E. sacrosanctus); 3) life form morphogenesis taking into account its polyvariety for all Far Eastern species according to the approach by Bezdelev \& Bezdeleva (2006); 4) taxonomic status of some species in the neighboring countries (Russia, DPRK and Republic of Korea, China and Japan).

\section{LITERAT URE CITED}

Baranov, V.I. 1998. Seasonal rhythms in development of spindle-tree (Euonymus L., Celastraceae R.Br.) in the Far East. In: Plants in monsoonal climate I. (V.A. Nedoluzhko, ed.), pp. 147-149, Vladivostok (in Russian). [Баранов В.И. 1998. Сезонные ритмы развития бересклета (Еиопуmus L., Celastraceae R.Br.) российского Аальнего Востока // Растения в муссонном климате / под реА. В.А. Недолужко. ВАадивосток. С. 147-149].

Baranov, V.I. 1999. The state and prospects of studying the Celastraceae family in the Russian Far East. In: Study of the vegetation cover of the Russian Far East (Proceedings of the Botanical Gardens of the FEB RAS, Vol. 1, (V.A. Nedoluzhko, ed.), pp. 67-70, Vladivostok (in Russian). [Баранов В.И. 1999. Состояние и перспективы изучения семейства бересклетовых на российском Аальнем Востоке // Исследование растительного покрова российского Аальнего Востока (Труды ботанических садов $\triangle \mathrm{BO}$ РАН, Т. 1 / под реА. В.А. НеАолужко. С. 67-70].

Barkalov, V.Yu. 2009. Flora of the Kuril islands. Dalnauka, Vladivostok, 468 pp. (in Russian). [Баркалов B.Ю. 2009. ФАора Курильских островов. ВАацивосток: Аальнаука, 468 с.].

Bezdelev, A.B. \& T.A. Bezdeleva 2006. Life forms of seed plants of the Russian Far East. Dalnauka, Vladivostok, 296 pp. (in Russian). [Безделев А.Б., Безделева Т.А. 2006. Жизненные формы семенных растений российского Аальнего Востока. ВАадивосток: Аальнаука, 296 с.].

Blakelock, R.A. 1951. A synopsis of the genus Euonymus L. Kew Bulletin 2:210-290.

Cherepanov, S.K. 1994. Vascular plants of Russia and adjacent states (the former USSR). Cambridge University Press, Cambridge (USA), 516 pp.

Ka, N. 2006. Celastraceae. In: New flora of Korea, vol. 1. (Lee, Y.N., ed.), pp. 709-716, Kyo-Hak Publ. Co., Ltd., Seoul.

Kim, J.H. \& Y.S. Kim 1994a. A taxonomic study of Korean Euonymus L. (Celastraceae) based on the morphology of vegetative characters. Korean Journal of Plant Taxonomy 24(4):215-230.

Kim, J.H. \& Y.S. Kim 1994b. A taxonomic study of Korean Euonymus L. (Celastraceae) based on the morphology of reproductive characters. Korean Journal of Plant Taxonomy 24(4):231-245.

Kim, J.H. \& Y.S. Kim 1994c. A taxonomic study of Korean Euonymus L. (Celastraceae) based on the anatomical cha- 
racters. Korean Journal of Plant Taxonomy 24(2):61-71.

Kim, J.H., B.H. Choi \& Y.S. Kim 1997. Numerical taxonomy of Euonymus L. (Celastraceae) in Korea. Korean Journal of Plant Taxonomy 27(3):331-348.

Kiseleva, K.V. 1988. Family Celastraceae Lindl. In: Vascular plants of the Soviet Far East, vol. 3 (S.S. Kharkevich, ed.), pp. 152-159, Nauka, Leningrad (in Russian). [Киселева К.В. 1988. Семейство Celastraceae Lindl. / / Сосудистые растения советского Аальнего Востока / поА реА. С.С. Харкевича. АенинграА: Наука. Т. 3. С. 152-159].

Komarov, V.L. 1904. Flora of Manchuria. In: Proceedings of the Imperial St. Petersburg botanical garden, vol. 2, part 2, pp. 703-719 (in Russian). [Комаров В.А. 1904. ФАора Маньчжуріи / / Труды Императорского Санкт Петербургского ботанического саАа. Т. 2, ч. 2. С. 703-719].

Komarov, V.L. 1908. Introduction to the flora of China and Mongolia. In: Proceedings of the Imperial St. Petersburg botanical garden, vol. 29, 388 pp. (in Russian). [Комаров B. $\Lambda$. 1908. Введеніе къ флорамъ Китая и Монголіи / / Труды Императорского Санкт Петербургского ботанического сада. Т. 29. 388 с. + ХХ табл.].

Krishtofovich, A.N. 1914. Celastraceae. In: Flora of Asian Russia, issue 5 (B.A. Fedtchenko, ed.), pp. 14-33 (in Russian). [Криштофович А.Н. 1914. Celastraceae / / ФАора Азиатской России / под реА. Б.А. ФеАченко Вып. 5. C. 14-33].

Ledebour, C.F. 1842. Flora Rossica sive enumeratio Plantarum in totius Imperii Rossici. Stuttgartiae. $790 \mathrm{~s} .+22 \mathrm{~s}$.

Leonova, T.G. 1974. The genus Euonymus L. of the USSR and neighboring countries. Nauka, Leningrad, 132 pp. (in Russian). [Аеонова Т.Г. 1974. Бересклеты СССР и сопреАельных стран. $\Lambda .:$ Наука. 132 с.].

Loesener, Th. 1942. Celastraceae. In: Die Naturlishen Pflanzenfamilien, $20 b$ (A. Engler \& K. Prantl, eds), ss. 87-197, Leipzig, Berlin.

Ma, J.-S. 2001. A revision of Euonymus (Celastraceae). Thaiszia - Journal of Botany 11(1/2):1-264.

Ma, J.-S. \& A.M. Funston 2008. Celastraceae, Euonymus. In: Flora of China. Vol. 11 (Oxalidaceae through Aceraceae) (Z.Y. Wu, P.H. Raven \& D.Y. Hong, eds), pp. 440-463 pp., Science Press, Beijing, and Missouri Botanical Garden Press, St. Louis.

Maack, R.K. 1859. A trip to the Amur River, made by order of the Siberian Department of the Imperial Russian Geographical Society in 1855 by R.K. Maak. S.F. Soloviov, St. Petersburg, 577 pp. (in old Russian). [Маак Р.К. 1859. Путешествіе на Амуръ, совершенное по распоряженію Сибирскаго отдела Императорскаго русскаго географическаго общества въ 1855 г., Р.К. Маакомъ. Санкт-Петербург: С.Ф. Соловьёв. 577 с.].

Maximovicz, C. 1859. Primitiae florae amurensis. Versuch einer Flora des Amurlandes. Mémoires de l'Académie impériale des sciences de St. Pétersbourg 9:1-504. 10 Taf., 1 Kart.

Maximowicz, C. 1881 (1882). Diagnoses plantarum asiaticarum. Bulletin of the Academy of Sciences of St. Pétersbourg 4:23-32.

Maximowicz, C. 1889. Flora tangutica sive Enumeratio plantarum regionis Tangut (Amdo) provinciae Kansu, nec non Tibetiae praesertim orientaliborealis atque Tsaidam, 1. Petropoli, typis Academiae imperialis scientiarum petropolitanae. $114 \mathrm{pp}$.

Moiseenko, S.N. 1954. Spindle trees of the Far East. Khabarovskoe knizhnoe izdatelstvo, Khabarovsk, 63 pp. (in Russian). [Моисеенко С.Н. 1954. Бересклеты Аальнего Востока. Хабаровск: Хабаровск. книжн. издат. 63 с.].
Nakai, T. 1934. Genitia, gen. novum Celastracearum. Systema novum generis Euonymi Nipponensis. Acta Phytotaxonomica et Geobotanica (Kyoto) 13:20-32.

Nakai, T. 1943. Ordines, familiae, tribi, genera, sectiones, species, variatates, formae et combinationes novae a Prof. Nakai-Takenoschin adhuc et edita. Appendix: Questiones characterium naturalium plantarum. Imperial University, Tokyo.

Nedoluzhko, V.A. 1995. The conspectus of the dendroflora of the Russian Far East. Nauka, Vladivostok: 208 pp. (in Russian). [Недолужко В.А. 1995. Конспект денАрофлоры российского Аальнего Востока. ВАадивосток: Аальнаука. 208 с.].

Ohwi, J. 1984. Flora of Japan (in English). Smithsonian Institution, Washington, 1067 pp.

Prokhanov, Ya.I. 1949. Family Celastraceae Lindl. In: Flora of the USSR, Vol. 14 (B.K. Shishkin \& E.G. Bobrov, eds), pp. 552-577, Izdatelstvo Akademii Nauk SSSR, Moskva, Leningrad (in Russian). [Проханов Я.И. 1949. Семейство Celastraceae Lindl. // ФАора СССР / под реА. Б.К. Шишкина и Е.Г. Боброва. М.-А.: ИзА-во АН CССР. T. 14. C. 552-577].

Prokhanov, Ya.I. 1960. The conspectus of system of the spindle-trees family of the USSR. Additions and changes. Botanicheskie Materialy Gerbariya Botanicheskogo Instituta AN SSSR 20:409-412 (in Russian). [Проханов Я.И. 1960. Конспект системы бересклетовых СССР. Аобавления и изменения // Ботан. матер. герб. Бот. ин-та АН CCCP. T. 20. C. 409-412].

Regel, E.A. 1861. Tentamen florae Ussuriensis. Mémoires de l'Académie impériale des sciences de St. Pétersbourg 4(4): XIII s. +228 s. + tab.

Regel, E. 1862. Experience on the flora of the Ussuri country on the basis of materials collected by R. Maack. Tipografia V. Bezobrazova i Ko, St. Petersburg (in old Russian). [Регель Э. 1862 Опыть фморы Усурійской страны составил по материаламъ, собраннымъ Р.Маакомъ. Санкт Петербург: Типографія В. Безобразова и комп. XXIV c. + 344 с. + табц., карт.].

Ruprecht, F. 1857. Die ersten botanischen Nachrichten über das Amurland. Zweite Abtheilung Bäume und Sträucher beobachtet von Richard Maack bestimmt. Bulletin de la Classe physico-mathématique de l'Académie impériale des sciences de St.-Pétersbourg 15:257-267, 352-383.

Savinov, I.A. 2009. Taxonomic survey of the Celastraceae R.Br. family in Russian and Ukrainian floras. Byulleten Moskovskogo Obshchestva Ispytatelei Prirody, Otdel Biologiya 114(2):58-68 (in Russian). [Савинов И.А. 2009. Таксономический обзор семейства Celastraceae R.Br. во флорах России и Украины // Бюль. МОИП. ОтА. биол. Т. 114, вып. 2. С. 58-68].

Savinov, I.A. 2011. New data on the diagnostic characters and distribution of some Far Eastern species of Euonymus L. (Celastraceae R.Br.). In: Biodiversity and environment of Far East reserves 1:66-70 (in Russian). [Савинов И.А. 2011. Новые Аанные о Аиагностических признаках и распространении некоторых дальневосточных видов Euonymus L. (Celastraceae R.Br.) // Биота и среда заповедников Аальнего Востока. Вып. 1. С. 66-70].

Savinov, I.A. \& K.S. Baikov 2007. The analysis of phylogenetic relations in the genus Euonymus L. (Celastraceae R.Br.) using SYNAP method. Turczaninowia 10(3-4): 36-50 (in Russian). [Савинов И.А., Байков К.С. 2007. Анализ филогенетических связей в роде Euonymus L. (Celastraceae R.Br.) с помощью метода SYNAP // Turczaninowia. T. 10, вып. 3-4. C. 36-50].

Savinov, I.A. \& N.A. Trusov 2018. Far Eastern species of Euonymus L. (Celastraceae): additional data on diagnostic 
characters and distribution. Botanica Pacifica 7(2):41-46.

Shimanovich, E.I. 1987. Spinde tree. In: Bibl. "Woody species". Agropromizdat, Moscow, 64 pp. (in Russian). [Шиманович Е.И. 1987. Бересклет // Биб̆. «Аревесные породы». М.: Агропромиздат. 64 с.].

Schmidt, F.B. 1874a. Amgun-Bureya flora. In: Proceedings of the Siberian Expedition of the Imperial Russian Geographical Society, vol. 2, pp. 7-84, Tipografiya Bratiev Panteleevykh, Saint Petersburg (in Russian). Шмилт Ф.Б. 1874а АмгуноБуреинская флора // Труды Сибирской Экспедиціи Императорскаго Русскаго географическаго общества. Санкт Петербург: Типографія братьев Пантелеевыхъ. T. 2. C. 7-84].

Schmidt, F.B. 1874b. Sakhalin flora. In: Proceedings of the Siberian Expedition of the Imperial Russian Geographical Society, vol. 2, pp. 85-233, Tipografiya Bratiev Panteleevykh, Saint Petersburg (in Russian). ШШмилт Ф.Б. 18746 Caхалинская флора // Труды Сибирской Экспедиціи Императорскаго Русскаго географическаго общества. Санкт Петербург: Типографія братьев Пантелеевыхъ. T. 2. C. 85-233].

Shukhobodsky, B.A. 1958. Gen. Euonymus. In: Trees and shrubs of the USSR. Wild, cultivated and promising for introduction, vol. 4 (S.Ya. Sokolov, ed.), pp. 358-390, Izdatelstvo Akademii Nauk SSSR, Moskva, Leningrad (in Russian). [Шухоболский Б.А. 1958. Род Еиопути // Аеревья и кустарники СССР. Аикорастущие, культивируемые и перспективные Аля интродукции / поА реА. С.Я. Соколова. М.; $\Lambda .:$ ИзА-во Академии наук СССР. Т. 4. С. 358-390].

Sugawara, S. 1940. Illustrated flora of Saghalien, vol. 3. P. 1270-1281.

Tatewaki, M. 1957. Geobotanical studies on the Kurile islands. Acta Horti gothoburgensis 21:43-123.

Thiers, B. [continuously updated]. Index Herbariorum: A global directory of public herbaria and associated staff. New York Botanical Garden's Virtual Herbarium. http:/ / sweetgum. nybg.org/ih/ (accessed 14 November 2021).

Thunberg, C.P. 1780. Kaempferus Illustratus. Nova acta Regiae Societatis Scientiarum Upsaliensis, 3.
Thunberg, C.P. 1784. Flora Japonica sistens plantas insularum japonicarum. Lipsiae: in Bibliopolio I.G. Mülleriano. 434 s.

Tolmachev, A.I. 1957. A new species of spindle tree from Sakhalin. Botanicheskie Materialy Gerbariya Botanicheskogo Instituta AN SSSR 18:157-162 (in Russian). [Толмачев A.И. 1957. Новый вид бересклета с Сахалина / / Бот. матер. Герб. Бот. инст. АН СССР. Т. 18. С. 157-162].

Tolmachev, A.I. 1959. About the flora of Sakhalin Island. In: The 12th Komarov Lectures, pp. 1-103, Izdatelstvo AN SSSR, Moskva, Leningrad (in Russian). [Толмачев А.И. 1959. О фморе острова Сахалин // XII Комаровские чтения. М.; А.: ИзА-во АН СССР. 103 с.].

Tolmachev, A.I. \& B.A. Shukhobodsky 1963. The spindletree genus of Sakhalin island. In: Trudy Sakhalinskogo Kompleksnogo Nauchno-Issledovatelskogo Instituta 13:13-54 (in Russian). [Толмачев А.И., Шухободский Б.А. 1963. Бересклеты острова Сахалина // Труды СахКНИИ. Вып. 13. С. 13-54].

Turczaninow, N. 1858. Animadversiones in secundam partem herbarii Turczaninowiani, nunc Universitatis Caesareae Charkowiensis. Bulletin de la Société impériale des naturalistes de Moscou 31(2):379-476.

Tzvelev, N.N. 2004. The family Celastraceae R.Br. In: Flora of Eastern Europe, vol. 11 (N.N. Tzlelev, ed.), pp. 437-449, KMK Press, Moskva (in Russian). [Цвелев Н.Н. 2004. Сем. Celastraceae R.Br. - Аревогуб̆цевые / / ФАора Восточной Европы / под реА. Н.Н. Цвелева. М.: Товарищество научных изданий КМК. Т. 11. С. 437-449].

Wang, C.H. 1936. The studies of Chinese Celastraceae. Chinese Journal of Botany 1(1):35-68.

Woroshilov, V.N. 1966. The flora of the Soviet Far East. Nauka, Moscow, 478 pp. (in Russian). [Ворошилов B.H. 1966. ФАора советского Аальнего Востока. М.: Наука. 478 с.]

Woroshilov, V.N. 1982. Plant identifier for the Soviet Far East. Nauka, Moscow, 672 pp. (in Russian). [Ворошилов B.H. 1982. Определитель растений советского Аальнего Востока. М.: Наука. 672 с.]. 